\title{
Truth, beauty, and goodness
}

\section{Defence of the past}

In the myth of Sisyphus, the King of Corinth pushes a great stone up a mountain, whereupon the stone rolls down to the plain again. To understand why Sisyphus apparently toils uselessly in the underworld, we can interrogate Sisyphus himself. Why are you pushing this great stone? Or we can interrogate Death, who has imposed this task, in order to secure an answer. And if Sisyphus or Death wanted, and was able, to reply, and if we could understand their answer, we could conclude our search.

Similarly, to understand the importance of history, memory, and heritage, why Ramses II's cliff temples were moved, we could interrogate the participants themselves or look for their justifications. What is the point of this enormous operation to save some old temples? Why this fascination with the past? Why tell about, remember, and preserve traces of distant ages? The intention would then be to uncover the motives through the participants' own justifications.

The justifications for the Nubian campaign were presented in 1960 by the then Director-General of UNESCO, Vittorino Veronese. An appeal described the threats from the Aswan High Dam; the difficult choice between the heritage of the past and well-being in the present and between temples and crops; and the call by the governments of Egypt and the Sudan for help from UNESCO. It stressed the possibility of new discoveries for humanity, and in return for this help the relevant countries would be opened up for archaeological excavation, with the possibility for half of all finds, as well as monuments, to go to foreign museums. The appeal described a noble cause, outlined a new era for Egyptology, and regarded the operation as a chance to demonstrate international solidarity with countries that had been at the centre of many conflicts over the centuries (Veronese 1960: 7). 
Veronese described heritage in a way that pointed towards both material and intangible world heritage:

Wondrous structures, ranking among the most magnificent on earth, are in danger of disappearing beneath the waters.... These monuments, whose loss may be tragically near, do not belong solely to the countries who hold them in trust. The whole world has the right to see them endure. They are part of a common heritage which comprises Socrates' message and the Ajanta frescoes, the walls of Uxmal and Beethoven's symphonies. Treasures of universal value are entitled to universal protection. (Veronese 1960: 7)

Today, a reader will be struck by the contrast between the elevated rhetoric and the promise later in the same text:

In return for the help the world gives them, the governments of Cairo and Khartoum will open the whole of their countries to archaeological excavation and will allow half of whatever works of art may be unearthed by science or by hazard to go to foreign museums. They will even agree to the transport, stone by stone, of certain monuments of Nubia. (Veronese 1960: 7)

The contrast is apparent half a century later, when questions concerning the return of heritage to its original location constantly create debate and conflicts.

Justifications and motives depend on who is speaking or writing, where, and when. The justifications of a Director-General of UNESCO represent one perspective, while the motives of participating governments, institutions and funds may be different, as may the motives of the people who actually carried out the work. Behind the wording about conflicts and solidarity, it is possible to sense the Suez crisis, when the UK, France, and Israel attacked Egypt after the nationalisation of the canal in 1956, a mere four years before. Of these three countries, only France - host to the headquarters of UNESCO - contributed to the campaign, and none of them subsequently accepted temples. And before the Director-General's appeal, there were several years of contacts and initiatives between political and antiquarian actors, a minister of culture, a Deputy Director-General, an Egyptologist, and many others (Säve-Söderbergh 1987: 64ff; 1996: 59ff).

Official justifications in rhetorical phrases, which are the result of a lengthy diplomatic process and have been negotiated to create a consensus that as many countries as possible can agree on, are only part of the background. And when the campaign was over, one of the central actors - the Egyptologist Torgny Säve-Söderbergh - was able, 
on behalf of UNESCO, to supplement previous justifications with higher employment in the area, income from tourism, and contacts created through the transfer of antiquities and monuments to other countries (Säve-Söderbergh 1987: 137, 217f; 1996: 114).

An exploration of justifications and motives will quickly reveal that they are numerous, highly diverse, and dependent on the discourses or conversations of which they form part. Justifications and motives are to be found across the whole field of history, memory, and heritage - from general humanities to individual disciplines or investigations. Justifications and motives may be directed outwards at society as a whole, or inwards in a definition of areas of responsibility or territories; both cases involve a fight for attention and resources. Historical overviews of shifting justifications are presented; or it is possible to read the author's personal view of what are, can, or ought to be the right motives. Justifications and motives may glide from an account of why over to a methodological discussion about how; that is, about whether useful results are best achieved through freedom or control, through basic research or applied research, and through the prioritisation of one field ahead of another.

The usefulness of the humanities can be asserted in relation to economics, social science, medicine, natural science, and engineering. Motives can be discussed from a philosophy-of-history perspective, with analyses of how different periods viewed usefulness. Accounts of different motives can be presented in textbooks. Justifications that come across as rhetorical slogans for the already initiated may appear in an appeal or at the inauguration of a memorial, a new museum, or a new initiative: The past for the future! History, heritage, and memory as a resource! Democracy and dialogue! Justifications may also be given in formal decisions about archaeological investigations or the protection of buildings, and may then include references to legislation or conventions. But where the first and canonical culture of heritage is geared to expressing justifications using rhetoric, arguments, or statutory provisions, the second and critical culture of heritage wants to put in question marks as an expression of scepticism.

There is a long tradition of reflecting on what history is, can be, or should be, on the development of history, and on the history, perspectives, methods, and sources of the study of history itself. Many have argued for the usefulness of history or discussed the arguments of others. These reflections on history have been conducted by historians, but also by philosophers and others under the heading "philosophy of history". 
In the course of these discussions, many participants have been inspired by the philosopher and philologist Friedrich Nietzsche and his Vom Nutzen und Nachtheil der Historie für das Leben (On the Use and Abuse of History). According to Nietzsche, the usefulness of history may be divided into three categories, the monumental, the antiquarian, and the critical. The monumental provides force for action through examples. The antiquarian admires, cultivates, and preserves the past with reverence. The critical shows the suffering person the path to emancipation (Nietzsche 1874 (German): ch. 2-3; 2005 (English): ch. II 12ff, III 17ff).

Nietzsche criticised the German society of his time, his opinion being that knowledge of past origins had come to exert an unhealthily great influence (cf. Latour 1991 (French): 93f; 1993 (English): 69). He was particularly critical of the antiquarian attitude in which all of the past was considered valuable. Nietzsche missed the balance in Ancient Greece between history and life, between knowledge and art. The three uses - the monumental, the antiquarian, and the critical - needed to be balanced.

Nietzsche's trinity has been updated and supplemented by the economic historian Svante Beckman. Employing more contemporary terms, the monumental use might, according to Beckman, contribute to social order and collective identity; the antiquarian use might contribute to knowledge and individual security; and the critical use might contribute to enlightenment and social development. Beckman then adds a fourth category, playful use, in which the past can contribute to individual experiences and entertainment. But as a typical representative of the critical culture of heritage, Beckman emphasises the unfavourable aspects: the monumental can also legitimise power and lies, assisting in repression; the antiquarian can contribute to escapism and afford false consolation; the critical can contribute to alienation and trivialisation - and the playful can contribute to lies, escape, aestheticisation, and trivialisation. The new set of four categories is based on Beckman's view that all actions can be explained with reference to norms (monumental), necessity (antiquarian), usefulness (critical), and entertainment (playful) (Beckman 1998: 39ff; 2005: 335ff; cf. 1997).

The uses of history can be identified through history itself, by exploring the justifications stated by historians themselves. Familiar and still relevant themes and motives turn up at an early stage, in Herodotus and Ibn Khaldûn, for instance: history is tremendously popular across national borders, peoples, and social groups. 
History has several purposes - gathering knowledge so as to be able to describe, understand, and explain both the past and the present, narrating so as to entertain and to counter oblivion. And history searches for truth, strives after beauty in its style, and possesses both ethical and philosophical dimensions.

Herodotus, who has been called the "father of history", thus began his work Histories from the fifth century BCE with these words:

What Herodotus the Halicarnassian has learnt by inquiry is here set forth: in order that so the memory of the past may not be blotted out from among men by time, and that great and marvellous deeds done by Greek and foreigners and especially the reason why they warred against each other may not lack renown. (Herodotus I: 1, p. 3)

The historian and politician Ibn Khaldûn supplied an insightful presentation of several purposes of history in his foreword to The Muqaddimab: An Introduction to History from 1377:

HISTORY is a discipline widely cultivated among nations and races. It is eagerly sought after. The men in the street, the ordinary people, aspire to know it. Kings and leaders vie for it. Both the learned and the ignorant are able to understand it. For on the surface history is no more than information about political events, dynasties, and occurrences of the remote past, elegantly presented and spiced with proverbs. It serves to entertain large, crowded gatherings and brings to us an understanding of human affairs. [It shows] how changing conditions affected [human affairs], how certain dynasties came to occupy an ever wider space in the world, and how they settled the earth until they heard the call and their time was up. The inner meaning of history, on the other hand, involves speculation and an attempt to get at the truth, subtle explanation of the causes and origins of existing things, and deep knowledge of the how and why of events. [History,] therefore, is firmly rooted in philosophy. It deserves to be accounted a branch of [philosophy]. (Khaldûn 1958: vol. 1, Foreword, p. 6)

But history is full of varying justifications and motives. History and philosophy of history is such a broad field that there is room for a specialisation or a genre of literature that answers the question: Why history? (e.g. Southgate 1996; 2000; 2005; Evans 1997; Tosh 2008). The answers primarily reflect their time and place; but they are also an attempt to influence what direction the discipline should take in the future, and here the authors' own positions become visible. 
In a surviving manuscript called Apologie pour l'histoire ou Métier de l'historien (The Historian's Craft), the Annales historian Marc Bloch began by reporting a question: "Papa, expliquemoi donc à quoi sert l'histoire" ("Tell me, Daddy. What is the use of history?"). Bloch was executed by the Gestapo as a member of the Resistance, so the book that was to be the answer was never completed. Even so, the answer is clear from the subsequently published manuscript. The purpose of history is to understand the present through the past, and to understand the past through the present (Bloch 1949 (French): ix quotation, 11ff; 1992 (English): 3 quotation, 32ff).) So history is justified by a need for historical understanding, in which the past and the present are entangled.

The time and place can be almost identical and yet perspectives may differ widely, as is seen from two historians who were of the same age, were both trained in Cambridge and were both active for periods in New York, and who both wrote about Europe in the nineteenth and twentieth centuries: David Thomson and Eric Hobsbawm. While Thomson in The Aims of History stressed the importance of a historical attitude, of historical awareness and understanding for the intellectual enrichment of life (Thomson 1969: 11, 99ff), Hobsbawm in his article "Looking Forward: History and the Future" wanted to use history to make predictions or forecasts about the future, which he considered desirable, possible, and necessary (Hobsbawm 1981).

Archaeology focuses on excavating, documenting, analysing, interpreting, and communicating material culture, on developing new methods, and on discussing theoretical perspectives; that is, questions about what and how. On the rare occasions when the "why" of archaeology is discussed in an introduction or in a section of a chapter, this is generally done with reference both to the value of a long temporal perspective and to the specific advantages of exploring the material dimension. In both cases, the legitimation is indirectly related to the subject of history, to which a more limited perspective is ascribed, covering a relatively short period of time and wholly dependent on texts. Even in authoritative textbooks, the use of the past may be dealt with in a few lines under the heading "What use is the past?" - lines about the importance of feeling and knowing that there is a past, as well as about the importance of the past for learning more about what it means to be a human being, accompanied by a phrase such as "without our roots we are lost" (Renfrew \& Bahn 2016: 583f). 
One of the few exceptions to this summary treatment is to be found in an article about history of ideas by the archaeologist CarlAxel Moberg. The article "Den nyttiga fornforskningen" ("Useful [research on] Antiquity") (Moberg 1984; written in 1947, but updated) was produced after the Second World War as an explicit reaction to the previous (ab)use of archaeology, in Germany in particular. Moberg presented varying justifications for the study of the past, drawing on examples from Sweden and Denmark since the fifteenth century. The great majority reflect how the past has been of use in legitimising the state and its ideology. Native country and nation are thus the most commonly used concepts. Other central concepts are enlightenment, education, revolution, international solidarity - and, since the 1970s, entertainment and leisure activity.

When archaeologists discuss motives, there is generally an ulterior motive somewhere. When, for instance, Michael Shanks and Christopher Tilley illustrated connections between various justifications in Re-Constructing Archaeology, it was in an attempt to influence both theory and practice, and to establish a critical archaeology (Shanks \& Tilley 1987: 25ff, with Fig. 1.1). And when, in From Stonehenge to Las Vegas, Cornelius Holtorf presents different meanings of the past, his intention is to show that meaning varies over time, that it varies for different people, and that all meanings are equally important (Holtorf 2005: 78ff, 92ff). In both instances, the presentation of motives is used to promote a relativist programme.

Despite the multiple motivations and motives, it is possible to observe some expressions of concern that turn up at regular intervals in the debate - words such as threat, crisis, defence, and usefulness. The past is said to be threatened both from the outside and from the inside; consequently, the field is in crisis and needs to be defended, and this is then done with reference to its potential usefulness.

What these expressions have in common is that threat is both a concrete reality and a rhetorical figure. The texts and images of history are threatened by impermanence, but they may be preserved for posterity in archives and libraries. Memory is threatened by oblivion when new generations grow up, unless it is passed on by means of narration or documented. And heritage is threatened by decay and destruction and needs to be safeguarded. The cliff temples of Abu Simbel were threatened by flooding, but salvaged by being moved. New times mean new threats, which must be countered by new methods. Moreover, the whole field of humanities with 
history, memory, and heritage is seen as threatened by inner decay, which has allegedly deprived the field of its credibility and thereby rendered it useless; this is often attributed to harmful influences from modernity, Marxism, postmodernism, or postcolonialism.

Every time someone cries "crisis", however, it is necessary to ask oneself what their intention - their explicit or hidden agenda might be. For instance, when the humanities were said to be in crisis in 1970s Sweden, this was about a new generation wanting to reshape the field so as to make it more relevant to contemporary society (e.g. Forser 1978). And now that the humanities are described as being in crisis four or five decades later, it has to do with some people's contention that the criticism and influence from Marxism have gone too far (e.g. Nordin 2008). The word crisis is used to create attention, set a new agenda, redefine a field, and then reprioritise resources.

External and internal threats demand a defence. The past needs to be defended against threatening changes through archiving, documentation, conservation, restoration, relocations, or legislation. The past needs to be defended against threats from other competing fields according to which the past is of no use. Finally, the past needs to be defended against threats within the field which undermine its credibility. The defensive position is seen directly in book titles such as Apologie pour l'histoire ... (The Historian's Craft; Bloch 1949) and In Defense of History (Evans 1997). The fundamental point, in my view, is that the occurrence of numerous justifications and motives, as well as the febrile identification of values, actually constitutes a manifestation of the fact that history, memory, and heritage are, or are perceived as being, under attack on several flanks.

The threats are met by going on the offensive and asserting the use of the humanities and the past. We thus see titles of articles and books that could easily have ended with exclamation marks: "Den nyttiga fornforskningen" ("Useful [research on] Antiquity"), Why History Matters, Why the Past Matters, Archaeology Matters, and The Value of the Humanities (Moberg 1984; Tosh 2008; Little 2007; Sabloff 2008; Small 2013).

In a time, at a place, and in a society in which C. P. Snow's two cultures are again being marshalled against each other in the fight for limited resources, in which a distinction is made between what generates and what consumes resources, in which usefulness is associated with economics, social science, medicine, natural science, and engineering, whereas pleasure is associated with humanities, literature, and art, in which usefulness is fundamentally something 
defined by economic growth as both a means and an end - in such a situation, the past with its history, memory, and heritage is also obliged to assert its use and value.

\section{The values of heritage}

Heritage is priceless! Every time heritage is threatened or actually destroyed, it is pointed out that heritage is priceless. The Islamic State (IS, or Daesh) had books burned and statues smashed in Mosul and blew up the ruined city of Nimrud in the spring of 2015, while I was writing this, and these are just a few topical examples in a long historical series of related events. In this context, the word "priceless" is the strongest expression that can be used in defence of heritage, and it appears across a broad field from UNESCO to the media; priceless means of very great or infinite value. The idea behind the wording is that heritage, like that which is sacred, belongs to a sphere of its own, independent of the market and of economics. So heritage neither can nor should be valued in money, or indeed measured in relation to anything else at all.

And still, paradoxically, heritage is valued all the time - and converted into money. As a rule, heritage is preserved with reference to its values, and value is a concept drawn precisely from the economic sphere. Valuations and values are therefore crucial to the selection and management of heritage. And if heritage is put up for sale - as happens every day, legally or illegally, with antiquities and art - then supply and demand on the market will soon set a price for the priceless. The statues in Mosul would also have been given a price, higher if they were originals, lower if they were copies. The market knows no limits.

Heritage's reference to values differs from history, memory, and archaeology, where justifications are normal; but every value could, in principle, be reformulated as a justification. From the outset, the values of heritage have been adopted and developed to serve national administrations of ancient or cultural monuments, but now they are also discussed and defined globally, for example in UNESCO. Consequently, the values of heritage belong first and foremost to a bureaucratic discourse in the first, canonical, culture of heritage, even though they can be discussed more widely.

One point of reference regarding the values of heritage, and an important inspiration in heritage management, has been the treatise by the art historian Alois Riegl, Der moderne Denkmalkultus, sein Wesen und seine Entstehung (Riegl 1903 (German); 1929 
(German); 1982 (English); "The Modern Cult of Monuments: Its Character and Origin"; cf. Arrhenius 2003: 135ff; 2012: 92ff). Riegl's treatise was written by way of preparation for new legislation to protect monuments in the dual monarchy of AustriaHungary, a legislation that was, however, never implemented.

Riegl perceived a historical development in the choice of values, took account of both feelings and reason, and distinguished between intentional and unintentional monuments ("gewollten wie [...] ungewollten Denkmahlen"), i.e. between the manifest and the latent; everything could thus become a monument. Riegl emphasised five values, divided between the past and the present - three Commemorative Values ("Erinnerungswerte"), namely AgeValue ("Alterswert"), Historical Value ("historischer Wert") and Intentional Commemorative Value ("gewollte[r] Erinnerungswert") - and two Present-Day Values ("Gegenwartswerte"), namely Use-Value ("Gebrauchswert") and Art-Value ("Kunstwert"); the latter, Art-Value, was in its turn divided into Newness-Value ("Neuheitswert") and Relative Art-Value ("relativer Kunstwert"). These values have to do with time, source value, intention, function, and aesthetics - art as new and in the present.

Riegl's original intention was to find objective criteria for selecting what was worth preserving, but he came to the conclusion that the values were relative and might come into conflict with one another. There might be a conflict between commemorative and present-day values - between, for instance, Age-Value and Use-Value, Age-Value and Art-Value - and there could also be conflicts within one of the groups, that is to say, between Age-Value, Historical Value, and Intentional Commemorative Value. And the choice of restoration method will depend on which values are given priority.

Values are therefore not something that can be discovered but something that must be constructed. Every period and culture must formulate its own values, just as they choose their own justifications and motives. Objective justifications, motives, and values are a logical impossibility. However, there are many initiatives whose purpose is to attain national or universal consensus on values in, for example, national legislation and international conventions such as the Universal Declaration of Human Rights (1948) and the World Heritage Convention (1972).

Ever since Riegl's innovative treatise, there has been an extensive and sustained debate about heritage values. This debate takes place within and between the two cultures of heritage. The debate is primarily driven by the need that public authorities and museums 
have to be able to manage a constantly growing heritage in a both flexible and credible way in relation to other stakeholders in society. On the one hand, the criteria are expected to be so precise that they can be used in order to appraise and rank; on the other, they should be so open or so numerous that they can capture a constantly expanding heritage. But the debate is also driven forward by the critical culture of heritage, which has put question marks against established values and often argues for alternative ones or other priorities.

The debate has cast light on the values of varying periods from a historical perspective and discussed them in relation to various theoretical points of departure. Historical and theoretical perspectives are frequently combined in attempts to develop heritage management and produce selection and prioritisation criteria (e.g. Hygen 1996; Carlie \& Kretz 1998; Navrud \& Ready 2002; Pettersson 2003; Jensen 2010; Smith et al. 2010; Golinelli 2015). As a consequence of management needs and heritage growth, a constantly rising number of criteria are defined in sophisticated value systems.

Heritage is often managed along with the environment, so the landscape's cultural and natural environment can either complement each other or become integrated. And the wording according to which heritage is a resource, and thus has value as a kind of energy source, is taken from an environmental perspective. Explanations of the importance of heritage may hence refer to heritage being a resource without any real arguments or specific information. Heritage as a resource functions as a silently accepted slogan to which additional positive words such as "active" or "democracy" can be added. Phrases that posit heritage as a resource appear along these lines in titles of books, reports, conferences, campaigns, and centres - and they even do so across the two cultures of heritage (e.g. Tunbridge \& Ashworth 1996; Weissglas et al. 2002; Holtorf 2005: 130ff; Liliequist 2005).

The opposite view is also abundantly represented - that heritage is a liability, a problem and an obstacle, or, in short, that heritage is of no value. This criticism was given its most forceful expression by David Lowenthal in the 1990s, with derogatory words about heritage such as oppressive, defeatist, decadent, hyped, nostalgic, alarming, causes chaos, rubbish, sacred cow, corrupted, popularised, commoditised, politicised, ignorance, error, and biased (Lowenthal 1997: ix, 5ff, 10ff, 87ff, 121f).

Heritage can also represent events or phenomena that are so controversial, unpleasant, or marginalised that dealing with them 
can be problematic - there is often an association with politics, war, death, crime, or disease (cf. Tunbridge \& Ashworth 1996; Meskell 2002; Jönsson \& Svensson 2005; Logan \& Reeves 2009; Macdonald 2009). In the case of Auschwitz-Birkenau, which became a World Heritage site in 1979, the choice that was made was to preserve and remember (WHL 31, 1979). But in other cases it may be better to choose not to tell, remember, or preserve. For example, the so-called "Führerbunker" in Berlin is not accessible; instead, it was intentionally destroyed and the site built on. And even if the bunker can be claimed to form unique (negative) evidence of a cultural tradition and human history, it is not under consideration as World Heritage.

Finally, antiquarians and archaeologists want to be able, in their everyday lives, to encounter politicians, entrepreneurs, journalists, and others who claim - from the edge of the excavation site or in the media - that ancient monuments are of no value, that excavations and archaeologists are a financial liability, and that the traces of the past are an obstacle to progress.

If calculations of the monetary value of "priceless" heritage are controversial, the value of heritage for tourism and economic development is stressed in countless contexts. Heritage should be protected, preserved, and communicated to increase tourism; indeed, this is supposed to be the very raison d'être of heritage. And when a monument, a building, a site, or a landscape is inscribed as a World Heritage site, there are often great expectations of an increase in tourism and development; one example is when the southern part of the island of Öland in Sweden was so designated (WHL 968, 2000). It is a fact that some of the world's most important destinations are actually World Heritage sites, but they were well known to tourists long before the establishment of World Heritage as a concept - Notre-Dame in Paris (WHL 600, 1991), the pyramids in Giza in Egypt (WHL 86, 1979), the Taj Mahal in India (WHL 252, 1983), and the Statue of Liberty in New York (WHL 307, 1984). Abu Simbel thus became a tourist destination back in the nineteenth century.

Heritage tourism is an important part of a constantly growing tourist industry that boosts land, sea, and air transport and promotes shops and hotels, museums, and visitor centres; it is therefore of importance for employment and the economy. Consequently, the literature about heritage tourism and the relationship between heritage, tourism, and the economy is extensive (e.g. KirshenblattGimblett 1998; Graham et al. 2000: 129ff; Timothy 2011). 
Sometimes the significance of heritage is reduced to its role in tourism. But to try to understand or explain the attraction of heritage by means of tourism merely amounts to reformulating the fundamental problem. What, then, are the justifications, motives, or values of the pilgrimage, the educational tour, or tourism? People from both the host country and abroad may visit heritage sites for several reasons (cf. MacCannell 1976; Löfgren et al. 1990; Urry 1990; Grinder-Hansen 1992); they may, for instance, go there in order to increase their knowledge or to have a good experience, or perhaps out of a sense of duty.

What can or should be heritage, how can or should the value of heritage be determined - and how is this to be carried out? Normally the whole process is handled by academically trained antiquarian experts, who work on heritage management at the local, regional, central government, or international level, on the basis of a number of qualitative criteria formulated for this specific purpose.

Under the pressure of having to act in a society in which most values are determined in a market, and in which economic growth has high priority, attempts are made to bring out the values of heritage as clear and competitive. In this context, various tendencies are discernible. There are, for instance, attempts to systematise the actual process with well-defined (objective) value criteria that can be used in heritage management (e.g. Carlie \& Kretz 1998; Unnerbäck 2002). More rarely, attempts are made to convert cultural historical values into a (subjective) market price, in which valuation by consumers is given an influence (e.g. Almevik \& Fridén 1996).

In both instances, the idea is that it should be possible to measure and weigh heritage in relation to other interests, such as nature, roads, railways, bridges, tunnels, building development and industry. The question is not whether heritage is valuable, but what is the right currency and amount for heritage. However, the calculation of the value of heritage using money as the metric is controversial within the canonical culture of management; it is fine for heritage to result in income, but not for it to be seen as an expense. The idea of the independence of the field must not be undermined.

Heritage and democracy are words with several meanings. The concept of democratic heritage expresses the ambition of opening the field to the public, of engaging users, and of including those users in endeavours to set priorities regarding the traces of the past (e.g. Alzén \& Aronsson 2006). The intention behind the European Convention on the Value of Cultural Heritage for Society (2005), also called the Faro Convention, was thus to involve the public. But 
this can also be a critical strategy for intentionally or unintentionally disarming management experts, when members of the public are themselves allowed to determine what is to be heritage and what is not. Here the dividing lines between the canonical and the critical may be blurred (e.g. Holtorf 2013b; Schofield 2014).

In this context, democracy can mean another way of letting supply and demand in the market determine heritage values. The monetary market is replaced by a market of votes, under the encouragement or guidance of critical experts. But it is hardly the supply of "pastness" that governs the process, for then heritage from the very oldest periods - extremely little of which has been preserved would be most attractive. The experience of relevance is more likely to be the decisive factor, and this brings contemporary heritage into focus along with nostalgic traces linked to people's own childhood and youth.

Irrespective of how many, how detailed, or how sophisticated the accounts of various criteria in hierarchies and systems are, values still constitute an appraisal, however. And irrespective of all the governing documents, the criteria appear to be values that are open to interpretation and therefore, of necessity, subjective. They are values that a large number of experts have been able to agree on, based on a practice regarding the ways in which heritage has been assessed historically. But they remain values that express the view of a number of individuals at a particular time and in a particular place.

Heritage values and the associated debate can easily be identified at Abu Simbel. Thus the temples of Abu Simbel have also been called priceless, for instance by the Egyptian Minister of Culture, Sarwat Okasha, who was one of the initiators of the Nubian salvage campaign (Desroches-Noblecourt \& Gerster 1968: 9). At the same time, an exact price can be put on the preservation of the temples, just as their values as World Heritage have been laid down by UNESCO. The salvage campaign for the two temples at Abu Simbel alone cost about USD 40 million (Säve-Söderbergh 1987: 104).

Riegl's systematisation of values is still relevant for an understanding of Abu Simbel as heritage: the more than 3000-year-old temples testify to the passage of time; they are sources for the reign of Ramses II in particular; they were constructed as monuments to communicate political and religious messages; they are now used as tourist attractions; and they also possess an aesthetic value, both when new and today. 
When a World Heritage site was established for "Nubian Monuments from Abu Simbel to Philae" in 1979, this was done on the grounds that it fulfilled three criteria: human creative genius, testimony to cultural tradition, and heritage associated with events of universal significance (WHL 88, 1979).

The temples were already visited by travellers in ancient times, as evidenced by Greek graffiti, and after their rediscovery in the nineteenth century they again became a tourist attraction. The European adventurers in the wake of Napoleon's Egyptian campaign opened the way for the mass tourism of later times. When the Nubian campaign was to be justified, one of the arguments during the process was that more tourism would entail economic benefits; and indeed Abu Simbel became a popular tourist destination (SäveSöderbergh 1987: 217f; 1996: 210).

The temples of Abu Simbel were constructed to be seen, admired, and used - and that is also the case today. But both the material monuments and the human subjects have changed. The temples that are seen, admired, and used have been changed in some respects, just as the visitors who continuously see, admire, and use them are new; but there is no sharp distinction between then and now, between what is lasting and what has changed. By degrees, their development has been characterised by ruptures as well as by continuity. The past is both a foreign and a well-known country.

Just as there is no lack of opinions about the past, there is thus no lack of justifications, motives or values, criteria or principles, either before or now. Far from it. The field is so diverse and so densely populated that an overview is needed, a new organising structure as an alternative to Nietzsche's three perspectives. For Nietzsche's trinity has been kept alive more by his famous name than by its current relevance. His trinity must be viewed against the background of the political left-right scale with its social and economic issues, which was on the agenda in the nineteenth and twentieth centuries but has had competition, for better and worse, in the twenty-first century from issues to do with religion, culture, and identity, issues that may require another way of viewing the past and the present. Nonetheless, I find the question of where society and I myself are going more relevant and interesting than the question of where society and I are supposed to have come from, or who society and I "are".

Instead of formulating new arguments for the use of the past or defining new values, criteria, or principles to add to the existing stock, I am going to assert the reuse of a philosophical triad as a 
means of surveying, understanding, and explaining the whole field of history, memory, and heritage.

\section{Truth, beauty, and goodness}

Truth, beauty, and goodness are three perspectives that may serve as the starting point of three fundamental motives for understanding the meaning of the past. This triad, with roots in Western philosophy and theology, is useful both in order to obtain an overview of the multiple justifications, motives, values, and opinions about usefulness and in order to understand current conflicts around history, memory, and heritage. The triad of truth, beauty, and goodness is thus my alternative to Nietzsche's trinity of uses - the monumental, the antiquarian, and the critical.

Traditionally, the concepts of truth, beauty, and goodness are traced back through the history of philosophy to Plato. Three fields are then linked to the concepts - the fields of epistemology, aesthetics, and ethics; that is, the theories of knowledge, art, and morality, respectively. And in popular terms, the triad of truth, beauty, and goodness has come to stand both for philosophy as a project and for classical, but never irrelevant, virtues (e.g. Gardner 2011).

Truth, beauty, and goodness belong to the group of transcendental concepts. Medieval scholasticism developed a discussion about concepts said to transcend experience, concepts referred to as "the transcendentals" (transcendentalia). They included being (ens), one (unum), truth (verum), goodness (bonum), beauty (pulchrum), something (aliquid) and thing (res) (Gracia 1992). But just as truth, beauty, and goodness were not, in fact, treated as a distinct group of concepts by Plato - even though they are often presented as if they had been - scholasticism did not discuss them as a group either. The triad was only established as a distinct group when the Renaissance created a new synthesis between ancient pagan philosophy and medieval Christian theology.

Truth, beauty, and goodness were defined as a distinct group of transcendentals by the philosopher and canon Marsilio Ficino. As a commission for Cosimo de Medici, the leading businessman and politician in Florence, Ficino translated Plato's works from Greek to Latin for the first time, making them available in the West. Ficino's translation, lectures, and printed comments were of great importance for Platonism in the Renaissance and later. It was here, in the comments on Plato's dialogue Philebus (probably written in 1469, but only published in 1496), that the triad was established, and 
it was here that it was given a clear hierarchical structure. Ficino outlined a Platonic theology with three levels, from the body via the soul up to the intelligence, to being - that is, to God. According to Ficino, intelligence understands in order to attain the true, desires in order to attain the good, and acts to attain the beautiful (Allen 1975: 1ff, 48ff, 78f).

Subsequently, the triad figured in many contexts, for instance in the work of the philosopher Immanuel Kant in his three "critique" books - critique of pure reason, critique of practical reason, and critique of judgement; that is, his inquiry into the conditions for knowledge (Kant 1781 (German); 1998 (English)), ethics (Kant 1785 (German); 1998 (English)), and aesthetics (Kant 1790 (German); 2000 (English)). In the poet and theologist Esaias Tegnér, the concepts of the triad became the true, the right, and the beautiful in a poem entitled "Det Eviga" ("The Eternal"), which was written against the background of the Napoleonic Wars (Tegnér 1828: 192f). A related triad also turns up in the work of the philosopher Søren Kierkegaard in Stadier paa Livets Vei (Stages on Life's Way): the aesthetic, the ethical, and the religious (Kierkegaard 1845 (Danish); 1940 (English)). Here the aesthetic involves enjoyment and experience and the ethical concerns duty, truth being replaced by the religious dimension.

From Kant to the present, the concepts of the triad may be followed like a theme with variations in German philosophy, sociology, and history. In Theorie des kommunikativen Handelns (The Theory of Communicative Action), a discussion of the theories of the sociologist Max Weber, the sociologist Jürgen Habermas thus asserts that the transition to modernity is characterised by the institutionalisation of three types of rationality, three spheres of knowledge or values - the cognitive, the aesthetic, and the normative. These three spheres are said to correspond, in turn, to science with its criteria for truth, art with aesthetic criticism, and politics and law with rules for ethical and legal matters. With this division, mutual tensions necessarily arose between the spheres (Habermas 1981 (German): 1, 225ff, 233ff, 456; 1984 (English): 1, 157ff, 163ff, 340).

With a direct reference to Habermas, the historian Jörn Rüsen then identifies three dimensions of historical awareness, namely cognitive, aesthetic, and political values. These three are said to correspond to science, narrative, and power: reason, feeling, and will. Rüsen also stresses the possibility of tensions, imbalances, and hierarchies, perceiving them as arising between a cognitive 
strategy for knowledge production, an aesthetic strategy for the rhetoric and poetics of presentation, and, finally, a political strategy for collective memory. But none of the dimensions could be reduced to any one of the others (Rüsen 1994: 219ff; 2001: 49, $64,98)$.

A related triad can be found in Föreställningar om det förflutna "Images of the Past", an inquiry into archaeological reconstructions of Prehistory and the Middle Ages in Scandinavia. Here the archaeologist Bodil Petersson uses three perspectives, knowledge, adventure, and politics: knowledge through reconstructions, time travel as an adventure, and the political use of reconstructions (Petersson 2003: 15f).

Truth, beauty, or goodness - the useful knowledge of the Enlightenment, therapeutic narratives for times of crisis, or a moral duty to remind and remember? These three perspectives and possible uses of the past often end up opposing one another, their internal ranking changing over time. I have myself employed this triad, and the categories derived from it, to understand the contemporary debate about the role of archaeology in society in the article "Agenda arkeologi - upplysning, terapi eller moral" (Wienberg 2009; "Agenda archaeology - enlightenment, therapy, or moral"). Rhetorical phrases about renewing and democratising heritage and increasing its impact may hence, in actual fact, have to do with a desire to shift the perspective from the past to the present - and from knowledge to narrative and morality.

A polarising and totalitarian tendency can sometimes be seen to operate, with each of the perspectives wanting to dominate the debate: there is truth in the centre with a striving for knowledge, while beauty and goodness are subordinate. Or there is beauty with its narratives and entertainment in the centre; everything is narratives, and truth is not crucial. Then again, there is goodness with politics in the centre, whereas truth and beauty are subordinate. In concrete terms, the conflict between these perspectives may manifest itself as a conflict between science, which is supposed to represent striving for truth and is apt to reward original research results; media and media users, who are seeking entertaining stories irrespective of whether they are fact or fiction, moving on if the story being told is not sufficiently diverting; and, finally, politicians, parties, government agencies, and others that expect or demand usefulness to society, which is likely to be a rhetorical rephrasing of a demand that the field be subordinated to their particular agenda, whatever it might be. 
The triad of truth, beauty, and goodness may, at first sight, be thought of as permanent or timeless; but it most certainly is not. The triad recurs constantly in philosophy, since the concepts are open to interpretation. In their concrete form, the concepts are transitory with a short durability; each time, and also each place, has had its own ideas about the true, the beautiful, and the good. It is precisely because of their ability to change, to adapt to new conditions, to let themselves be reused with new content, that the concepts appear to be eternal. The triad is an example of how spolia from the past, whether material or intangible, building blocks or concepts, can be put to use in the present, carrying new meanings. In Renaissance Italy, whose style was inspired by ancient architecture, Ficino used concepts from Plato for new philosophical needs. With a more up-to-date designation, the Renaissance rebirth of Antiquity was a matter of creative reuse.

With the philologist and religious historian Georges Dumézil one can, if so inclined, identify a functional trinity in all IndoEuropean societies (Dumézil 1958). The reason is that sets of three concepts that embody a fascination with the geometry of the number three occur everywhere in religion, science, and politics. We find Hinduism's trimurti or trinity with the creator (Brahma), the preserver (Vishnu), and the destroyer (Shiva); the Christian Trinity with God the Father, the Son, and the Holy Ghost; the three holy kings Balthazar, Caspar, and Melchior; Islam's three holy cities Mecca, Medina, and Jerusalem; rhetoric's credibility (ethos), reason (logos), and emotion (pathos); the division into legislative, executive, and judicial power; the three kingdoms of nature - plants, animals, and minerals; the division of time into past, present, and future; the division of knowledge into reason, memory, and fantasy, or learning, experiencing, and reflecting; the archaeological system of three periods with the Stone Age, the Bronze Age, and the Iron Age; and Nietzsche's three uses - the monumental, the antiquarian, and the critical.

It is tempting to look at the triad of truth, beauty, and goodness and read three social groups into it: the thinking intellectuals, the working and entertained masses of the people, and the politicians taking action (Fredengren 2012: 196ff). This reading is a reasonable one since Plato, in his tract The Republic, divided citizens into three functional groups. The philosophers, like Plato himself, would govern; the artisans would work; and the soldiers would guard. According to Plato, these groups formed a hierarchy with the philosophers at the top and the artisans at the bottom. There was a 
parallel in the three parts of the body and the soul - the head for wisdom, the breast for will, and the stomach for desire (Plato 1997: 971ff). Plato's ideal state is later reflected in the medieval estates of the realm or the three orders, a church ideology for a society with three social and functional groups - oratores, those who pray, laboratores, those who work, and bellatores, those who fight (Duby 1978 (French); 1981 (English)). The Platonic triad also forms the basis of the trinity of thinking, willing, and judging that was discussed by the philosopher Hannah Arendt (Arendt 1981). But as all the examples demonstrate, there are many ways of interpreting the triad of truth, beauty, and goodness, which may also be seen either as a hierarchy or as virtues of equal standing.

Do we need the past? In Behövs det förflutna? ("Is the past needed?"), the philosopher Sören Halldén found three functions that can also be derived from the triad of truth, beauty, and goodness: learning from the past about the multifariousness of life, thereby gaining insights that may be put to use in solving problems; enrichment of life, such as a tourist's travels; and extension of experience, which can be used in making assessments. Halldén ends the book with the words, "this question opens up paths in different directions. It is a little like touching on the question "Why are you alive?" (Halldén 1983: 14f, quotation on 135).

No, it is more than a light touch on a fundamental question. For in order to give the past meaning, it is also necessary to give meaning to the present and the future. The past, the present, and the future flow into one another in an existential reflection: is the past needed - is the present needed - is the future needed? (cf. Wienberg 1999: 192, 196).

Anyone who expects to be given a clear and unequivocal answer to the question of why the past is needed must of necessity be either disappointed or deceived, for that would be the same as expecting a clear and simple answer to the question of why the present and the future are needed. In my opinion, truth, beauty, and goodness represent perspectives that complement one another with regard to what it means to be human. Homo sapiens, Homo narrans, and Homo ethicus - the thinking human, the storytelling human, and the engaged human.

Truth, beauty, and goodness complement one another without any internal ranking. No perspective is superior here, none can replace any other, and none can be dispensed with. Thus there is no hierarchy between the true, the beautiful, and the good, as was otherwise asserted by Ficino, Kant, and Kierkegaard; no social order, 
as in Plato or in the medieval notion of the estates of the realm. The true does not need to be beautiful or good; the beautiful does not need to be true or good; and the good does not need to be true or beautiful. Moreover, we are often confronted with the opposite of the triad, namely the false, the ugly, and the evil. In addition, the triad cannot be reduced to a duality without the loss of something significant. The truth, beauty, and goodness triad forms more than one complementarity, in which two parts complement one another. The three concepts constitute a "triplementarity", in which the three parts lend greater depth to one another.

\section{The truths of knowledge}

Knowledge about the past is desirable, useful, and essential. We need knowledge about the past to be able to understand or explain the present and meet the future. The ideal is truth, enlightenment, and progress, with science as the method. New knowledge is accumulated year by year.

Knowing and ability, science and knowledge, are words with immediately favourable connotations, but they can point in all directions. Knowledge can be an advantage or a disadvantage; it can enlighten or darken. Knowledge may be liberating; it can also be used to exercise power, or in an exclusionary social game. Knowledge can be seen as something that requires education and methodical training, or as something that is immediately available to everyone. In itself, knowledge is neither good nor bad. Knowledge like the past - can be used for everything.

Knowledge is quite fundamental, however, and it is something that characterises human beings - Homo sapiens, the thinking and understanding human. It is sufficient to try to imagine how quickly presentday society would break down without an enormous quantity of sophisticated knowledge about how something works, is, and was. But perhaps all knowledge is not necessary? Or is some knowledge more important or more useful than other knowledge?

As a species, Homo sapiens is said to be characterised precisely by its will to knowledge. Homo sapiens uses knowledge to understand and explain its surroundings and to search for meaning. Humans try not only to gather knowledge, but also to find and interpret patterns, even in what may be quite fortuitous; they constantly endeavour to understand and explain. And this search for meaning is said to have given the species an evolutionary advantage ahead of others: the ability, will, or compulsion to constantly look for causes 
and try to foresee what may come (Gärdenfors 2006). My own sense of wonderment about the meaning of history, memory, and heritage may thus be a typical example of a fundamental human character trait.

Knowledge as both an end and a means to an end has frequently been linked to the idea of progress and the Enlightenment project since the late seventeenth century. Rational knowledge was to replace irrationality, superstition, and dogmas. Knowledge attained through observation and experiment was to replace ancient and medieval speculation. Here knowledge and science in the West form part of a clash with the Church, acquiring a secular character in the process. Light becomes a metaphor for what is new in the Age of Enlightenment. Knowledge is thought to liberate humans and create an ever better future.

The ethos of the Age of Enlightenment was clearly formulated by the philosopher Immanuel Kant in the first lines of his contribution to a newspaper debate, "Beanwortung der Frage: Was ist Aufklärung?" ("An Answer to the Question: What is Enlightenment?"), lines that deserve to be quoted in full:

Aufklärung ist der Ausgang des Menschen aus seiner selbst verschuldeten Unmündigkeit. Unmündigkeit ist das Unvermögen, sich seines Verstandes ohne Leitung eines andern zu bedienen. Selbstverschuldet ist diese Unmündigkeit, wenn die Ursache derselben nicht am Mangel des Verstandes, sondern der Entschließung und des Muthes liegt, sich seiner ohne Leitung eines andern zu bedienen. Sapere aude! Habe Muth dich deines eigenen Verstandes zu bedienen! ist also der Wahlspruch der Aufklärung. (Kant 1784 (German): 481)

Enlightenment is the human being's emergence from his self-incurred minority. Minority is inability to make use of one's own understanding without direction from another. This minority is self-incurred when its cause lies not in lack of understanding but in lack of resolution and courage to use it without direction from another. Sapere aude! Have courage to make use of your own understanding! is thus the motto of enlightenment. (Kant 1996 (English): 17)

Science has knowledge as its goal, as is seen from the roots of the word in the Latin word scientia, meaning knowledge; science is the creation of knowledge. And even though this is not always formulated as an evident goal, it is apparent from the practice of science, in which all disciplines are very careful about their methods; that is, how to move in a more or less systematic way from questions to answers, using recognised methods. Historical and archaeological source criticism is one such method that is intended to ensure that 
the description of the past is founded only on sure facts. The purpose of source criticism is to uncover the way things actually were.

In the famous words of the historian Leopold Ranke (later von Ranke) from the foreword of Geschichte der romanischen und germanischen Völker von 1494 bis 1514 (History of the Latin and Teutonic Nations (1494 to 1514)), history was neither to judge the past nor to be of benefit to the future, but only to show what actually happened:

Man hat der Historie das Amt, die Vergangenheit zu richten, die Mitwelt zum Nutzen zukünftiger Jahre zu belehren, beygemessen: so hoher Aemter underwindet sich gegenwärtiger Versuch nicht: er will bloß sagen, wie es eigentlich gewesen. (Ranke 1824: Vf)

(To history has been assigned the office of judging the past, of instructing the present for the benefit of future ages. To such high offices this work does not aspire. It wants only to show what actually happened.)

But contrary to Ranke, explanations, motives, and values for history, memory, and heritage have generally been characterised by a historicist perspective since the nineteenth century. In historicism, at any rate in one of the ways in which the term is used, knowledge of the past is held to be crucial to the ability to understand and explain the present and shape the future. Historicism hence points both backwards and forwards in time. Historicism belongs together with modernity, which is said to be characterised by a historical awareness focusing on origins and development (e.g. Foucault 1966 (French); 1971 (English)).

The claim of historicism that the past can be used to shape the future has been criticised, though. In The Poverty of Historicism, which is a reckoning with the utopian ideologies of the 1920s and 1930s, the philosopher Karl Popper rejected the notion that there can be laws governing the development of history or of society, and that it is therefore impossible to predict or shape the future (Popper 1957). Popper's arguments resemble the chaos theory formulated long afterwards in the natural sciences and known for its "butterfly effect", in which decisive importance is ascribed to small variations and matters of chance. Both history and nature are chaotic or unstable systems sensitive to small differences, systems in which large changes do not need large explanations, and in which predictions demand an awareness of the values of all the relevant variables (Reisch 1991; Gerding \& Ingemark 1997). Therefore, tomorrow will always be different from what we had imagined or planned. 
The idea of progress and the Enlightenment project with its optimism have been criticised, and indeed heavily attacked, in recent years - as have knowledge and science. The Enlightenment idea of progress is reduced to just one of many ideologies. Michel Foucault and many others after him see the will to knowledge as a will to power (Foucault 1976 (French); 1990 (English)). Technological and organisational progress has a share in the responsibility for the worst genocide of the twentieth century, the Holocaust (Bauman 1989). Knowledge, facts, and truth, in particular, are called into doubt as concepts, goals, and means. Knowledge is said to be a social construction that can be negotiated in a laboratory (Latour \& Woolgar 1979). Enlightenment's radical doubt has been directed against enlightenment itself, reopening the door to irrationality, superstition, and dogma. Once again, human beings enter a state of folly and Unmündigkeit ("not of age", "incapacity"), to borrow Kant's term. The light of the Enlightenment is threatened by the darkness of dissolution.

Creating knowledge can either be a goal in itself or a means of attaining something else. When knowledge is a goal in itself, we can talk about knowledge as part of an educational project. When knowledge is a means of attaining something else, we can talk about an instrumental goal. However, the word instrumental is often used in a derogatory way in an implicit hierarchy, in which the elite's education is superior to the majority's practical knowledge.

When general education is stressed, especially in humanities disciplines, it might be expected to involve a democratic enlightenment project: Knowledge is intended to liberate human beings from the Unmündigkeit imposed on them. But if anything, it seems to emerge in order to disavow what is useful, instrumental, and practical. Bildung is ranked above mere education. In this context, the term Bildung may be regarded as a relic of another time, a time when the elite was supposed to acquire a broad spectrum of knowledge and proficiencies, a cultural code, so as to be able to function in state offices and mix at a distance from the rest of the population. To quote from the film Monty Python \& The Holy Grail (1975), when King Arthur manages to complicate a question about the air-speed velocity of an unladen swallow and is therefore free to cross the Bridge of Death: "Well, you have to know these things when you're a king, you know!" In more academic terms and with a reference to the sociologist Pierre Bourdieu, it could, instead, be said that redundant knowledge is used as symbolic capital in order to create social distance (cf. Bourdieu 1979 (French); 1984 (English)). 
Knowledge about the past as both an end and a means to an end is widespread, despite all the debate, doubt, and criticism. It is often so obvious and so generally accepted that there is no need to formulate it directly. In this respect, there is no interest in knowledge as a will to power or as a social marker, nor in science as an ideology. Instead, the whole focus is on how to attain knowledge. The past is narrated, remembered, preserved, excavated, reconstructed, and brought to life as both an alluring and essential source of knowledge.

The will to knowledge runs as an explicit or implicit theme though numerous examples: Herodotus, Ibn Khaldûn, Leopold Ranke, Friedrich Nietzsche, Marc Bloch, David Thomson, Eric Hobsbawm, and even Michel Foucault - they all pursued knowledge, and they all assumed that knowledge could be attained. In the introduction to Histoire de la sexualité (The History of Sexuality), Foucault thus linked the search for truth and enlightenment to liberation (Foucault 1976: 14 (French); 1990: 7 (English)); otherwise he, if anyone, represents a power-critical perspective on science and has inspired numerous postmodern relativists.

Returning to Abu Simbel, one motive for examining and salvaging the temples by moving them would be to secure them as sources of knowledge. As monuments, the temples are sources for the reign of Pharaoh Ramses II, for the art, cosmology, and politics of that period. More specifically, the great temple with its images and texts is one of several sources for the Battle of Kadesh in 1274 BCE between Egypt under the leadership of Ramses II and the Hittite Empire under the leadership of Muwatalli II. This well-documented battle, which took place at Homs in present-day Syria and in which thousands of chariots were used, is depicted as a huge victory for the pharaoh, even though that was hardly the case. A peace treaty, the earliest one known, was then made in 1258 вСе between the equally strong parties (Desroches Noblecourt 2007: 60ff, 134ff). So the depiction in the temple represents not the truth, but a partial truth, a pharaonic perspective on the past. Finally, the temples with their architecture, sculptures, images, and texts are also potential sources in a broader sense. Through the salvage campaign they have also been secured as sources in the future, sources to which scholars can return with new questions, perspectives, and methods.

With knowledge, facts, or even truth about the past both as means and ends, the good and the beautiful, morality and narrative, should be subordinate: it is irrelevant to truth how something is told, whether it is entertaining, or whether it is morally good or 
evil. All that matters is what something was actually like. But when the truth of the Enlightenment is called into doubt as a legitimate motive, the beauty of the narrative and the ethical demands come into play instead. It is not apparent that an increased will to knowledge is a major reason for greater present-day interest in the past.

\section{The beauties of narrative}

Narratives about the past are desirable, useful, and essential. We need narratives about the past in order to understand and explain the present, meet the future, and create social cohesion. The ideal is the beautiful, captivating, and engaging narrative - a narrative that can enlighten, entertain, and perhaps also impose an obligation. A narrative can also be ugly, harrowing, and not attended by any obligations at all, and we still listen or read eagerly in order to inhabit another time, another country, for a while.

A sense of alienation in periods of rapid economic upturn or falling expectations about the future during economic downturns can be compensated by a dose of nostalgic narrative from the country where "things were done differently". Consequently, when the UK entered a period of deindustrialisation and unemployment in the 1970s and 1980s, factories that had closed down were transformed into museums. "Real industry" was replaced by "heritage industry" (Hewison 1987). The unemployed were given work as uniformed guides, while others moved as time tourists through environments of Iron-Age settlements, trading places from the Viking era, medieval market towns, and Early Modern urban existence, all brought to life (Petersson 2003: 276ff). And at home we can be both enlightened and entertained by historical dramas such as Downton Abbey, about life on an English country estate in the decades after the loss of the Titanic. The past can offer a temporary refuge from the dreariness or problems of everyday life, and then it acts therapeutically. In narrative form, the past may contribute to health and reduce, or deflect attention from, the problems of the present (cf. Asplund Ingemark 2013).

Narratives about the past, the present, and the future are by no means new; indeed, they are something fundamental that characterises human beings - Homo narrans, the narrating and listening person (Niles 1999; Mankell \& Vera 2000). People use narrative as a tool to transfer experience (Gärdenfors 2006: 109ff; Boyd 2009). Mixtures of fact and fiction, of what has actually happened with what might or ought to happen, are thus found in oral narratives, 
in literary texts such as novels and short stories, in images such as rock carvings, paintings, photographs, and film, and in sculptures ranging from the limestone figure of Venus of Willendorf to present-day memorials. Without narratives, life would undoubtedly be much poorer, and perhaps impossible.

Back in the nineteenth century, as scientific disciplines emerged with their special genre of publications, seminars, and conferences, there was a parallel boom in historical narratives with an element of escapism. As part of the reaction of Romanticism to the Enlightenment project, the French Revolution, and the Napoleonic Wars, both science and art increased. Rational science was separated from speculative inquiry at the same time as there were constant crossings of borders.

Artists have interpreted the past, and scholars have written about it in literary modes. As examples of border-crossings between fact and fiction, between scholarship and art, and between two cultures, I select a pair of personal favourites from my bookshelf. On one side is the semioticist Umberto Eco, who was able to communicate his knowledge about semiotics, philosophy, literature, and the Middle Ages in his historical detective novel Il nome della rosa (Eco 1980 (Italian); 1983 (English), The Name of the Rose). And on the other side is the journalist and author Thorkild Hansen with Det lykkelige Arabien (Hansen 1962 (Danish); 1964 (English), Arabia Felix), who created a historical documentary novel and existential narrative about a Danish expedition to Yemen in the eighteenth century, which was at that time regarded as the happy "foreign country"; here Hansen was able to use his personal experience of the Nubian campaign. But many more names and works could obviously be mentioned.

Counterfactual history forms a popular genre of its own which crosses the border between fact and fiction. It is no longer a matter of what "actually happened" but of what could or perhaps ought to have happened, if events had taken another course. What if? Here historians and others can make creative forays beyond the confines of their disciplines and examine alternative histories. Early examples are known from the seventeenth century, but the genre has had an upturn since the 1990s. It often examines whether an alternative political or military development could have taken place after a certain point in time if something had been different. Here details, individuals, incidents, events, and the weather are given key roles. One source of inspiration is chaos theory, and the intention is to methodically examine possible explanations - and undoubtedly 
also to entertain (Ferguson 1997; Andersson \& Zander 1999; Evans 2014).

But what if the shape of Cleopatra's nose had been different, Duke William had been defeated at Hastings in 1066, Queen Kristina had not abdicated in 1654 , Napoleon had been victorious at Waterloo in 1815, Gavrilo Princip had missed in 1914, Günter Schabowski had replied differently in 1989, and Donald Trump had not won the Electoral College in 2016? Or what if Pharaoh Ramses II had been defeated at the Battle of Kadesh in 1274 вCE? Then the history of Egypt would have taken another turning, the pharaoh would have left a completely different legacy, and the temples of Abu Simbel would never have been built.

The border-crossings are numerous; but something new made its appearance with the postmodern criticism of the Enlightenment project, rational science, and "grand" narratives. There is a conscious shift from truth to beauty, from science to narrative, from fact to fiction, from grand to the small narratives, and from enlightenment to entertainment. More experiments are being made now than ever before with the form and content of history, memory, and heritage. And sometimes form is becoming more important than content.

The reckoning with the Enlightenment and rational science was accompanied by a "demasking" of the rhetorical character of research and communication. The texts of scholarship were viewed as a genre that could be subjected to textual analysis, as literary texts could. There has thus been an extensive debate about differences and similarities between fact and fiction, about what stories are told about the past, and about how the past can be (re)narrated (e.g. Solli 1996).

The historian Hayden White's Metahistory has attracted great attention with his inquiries into the rhetorical forms of historywriting, undertaken without White's regarding himself as a postmodernist or relativist. White claimed that history-writing was shaped by the literary templates of the nineteenth century - the romance, the comedy, the tragedy, and the satire. The romance, with metaphor as its expression, represents anarchy; the comedy, with metonymy, represents conservatism; the tragedy, with synecdoche, represents radicalism; and the satire, with irony, represents liberalism. History-writing is hence said to be steered by a fundamental poetics linked to political categories in which romance liberates while tragedy brings ruin, comedy reconciliation, and satire imprisonment (White 1973). 
A focus on narrative has also gained a foothold in archaeology and heritage studies. This is most clearly manifest in the work of the archaeologist Cornelius Holtorf, who in From Stonehenge to Las Vegas moves the focus from the past, and archaeology as a means of gaining knowledge of the past, to the present, archaeology and archaeologists becoming means of having experiences. According to this view, the meaning of archaeology is, first and foremost, located in its popularity as a metaphor for treasure hunting, adventurous fieldwork, and detective work. Furthermore, the narratives of science are no truer than other narratives about astrology, mysticism, or sacred geometry. Here and in other texts, Holtorf pushes a relativist and Enlightenment-critical line inspired by the philosopher Paul Feyerabend and his anarchist (or neoliberal) programme (Holtorf 2000; 2005; 2010). Feyerabend argued for a consistent "political relativism"; but in contrast to Holtorf, he explicitly rejected "philosophical relativism", which is the view that all traditions, theories, and ideas are equivalent (Feyerabend 1978: 82f).

Archaeology becomes part of a borderless popular culture in which people make a virtue of necessity or a virtue of a choice of political path. It is "tittytainment", a mixture of (breast) feeding and entertainment, bread and circuses, for the great mass of the population, who will not be needed in the world economy of the future; the term is said to have been coined by the sociologist and politician Zbigniew Brzezinski in a debate about the global economy of the future in San Francisco in 1995 between politicians, economists, and business leaders (cf. Martin \& Schumann 1996: $13 f$ (German); 1997: 4f (English)).

Popular culture requires no truths; nor does it require a distinction between science and literature, between history and myth, or between fact and fiction. For experience and for entertainment, it does not matter whether Bosnia has pyramids, whether Stonehenge was built by Druids, whether King Arthur existed, whether the trelleborgs were radio stations rather than Viking-age fortresses, whether the Holy Grail is hidden on Bornholm or in Scotland or Jordan, whether the Kensington Runestone is from the fourteenth or the nineteenth century, or whether Indiana Jones was actually a living person or is a fictional character (cf. Wienberg 2004; Fagan 2006).

To go back once more to Abu Simbel, one of the motives for examining and salvaging the temples was that it would be possible to have a fantastic experience (roughly) at the site in future, too. The 
temples were to continue to be a tourist destination. But ever since its construction, Abu Simbel has been a starting point for narratives. Ramses II had the great temple decorated with images showing how he defeated the Hittites at the Battle of Kadesh. The truth is that the battle was a draw - or even a defeat for the Egyptians. So the first narrative is a case of "alternative facts" - a propaganda lie. The temples are also the starting point for narratives about Ramses II as a powerful king with a desire to build, and about the religious ideas of the period (e.g. MacQuitty 1965). In Agatha Christie's crime novel Death on the Nile (Christie 1937), Abu Simbel is a backdrop to an intricate plot at the same time as the novel depicts the cruise of affluent Western tourists on the Nile, from Cairo and the pyramids in the north to the temples in the south.

A new narrative has been added since the salvage campaign of the 1960s, a narrative that focuses on the international operation and the technological achievements in moving and rebuilding the temples (e.g. Desroches-Noblecourt \& Gerster 1968). And then, every visitor, every tourist, can create their own narrative in their meeting with the temples. Even if the temples had not been salvaged, but had drowned when the Aswan High Dam was erected, the narratives would not have ceased. They would simply have been given a different and probably more nostalgic character.

But copies and films can also form starting points for narratives. The Crystal Palace in London, the main building in the first World Exhibition, housed a replica, erected in 1854, of the largest temple at Abu Simbel; the replica was destroyed in a fire in 1936 (Ossian 2007). Later, copies of varying sizes have been erected in many places - Pattaya in Thailand, Shenzhen in China, in the Luxor Hotel in Las Vegas in the US, and in Legoland at Billund in Denmark. The Italian amusement park Gardaland has an attraction called "Ramses: Il risveglio" ("Ramses: Awakening"), whose main entrance is designed as the great temple at Abu Simbel in half-scale (www.gardaland.it; cf. Melotti 2011: 81ff). In Portugal in 2011, the engineer and sculptor Hany Mustafa built a travelling exhibition called "Museo del templo Abu Simbel", which contained a glass fibre copy so that people would be able to experience the temple without needing to travel to an Egypt in turmoil. Finally, it is also possible to make a virtual visit to Abu Simbel.

The salvage campaign at the temples of Abu Simbel was also used in the film Erinnerungen an die Zukunft (Reinl 1970; Chariots of the Gods), a film based on books in which the author Erich von Däniken maintained that extraterrestrials had made visits to the 
earth in ancient times. In view of the enormous operation, with participants from many countries, that was necessary to move the temple in the modern period, von Däniken argued that the Egyptians could not have been capable of moving stones and doing construction work 3000 years previously. It must have been aliens from space, visits by “Gods" (cf. von Däniken 1973 (German): 60, Figs. 118-119; 1976 (English): 53f, Fig. 111a).

When beauty and fiction about the past are both means and ends, truth and goodness - knowledge and morality - must assume a subordinate position. For beauty and narrative it is generally, but not necessarily always, irrelevant whether something actually happened, existed, or is authentic, and also whether something is morally good or evil. All that matters is that the narrative is entertaining or serviceable. The truth is replaced by probabilities and possibilities. However, when the truth of the Enlightenment is doubted as a legitimate motive, and beauty and narrative are regarded as secondary, all that is left is the ethical demand.

\section{Ethical demands}

It may also be an ethical duty to protect and preserve the past from decay. We ought to preserve narratives about the past, preserve people's memories, and preserve the material and intangible traces of heritage. We are under an ethical demand to work actively so that history, memory, and heritage are not given lower priority, forgotten, or destroyed.

Ethics (or morality) is something fundamental that characterises humans - Homo ethicus, the engaged human, who enters into social ties with other people (e.g. Prozesky 2014). The concept of ethics comes from the Greek word ethikos, which is about manners or customs, whereas morality comes from the Latin word moralis, which is about customs or practices. Ethics and morality hence have the same core meaning, and they are often used interchangeably, even though ethics is normally defined as the theoretical or abstract starting point for the more practical or concrete sphere of morality. Irrespective of the choice of term, both concern people's endeavours to think, express, and do what is right - in other words, about people's striving towards that which is good.

But what, then, are the right and the good? The question opens up a limitless field of thoughts, recommendations, orders, statutes, and penalties. Ethics can have its starting point in religion, politics, philosophy, and culture. Ethics can be divided up into normative 
ethics and consequence-based ethics, or into virtues and duties. Ethics can form its own academic field of knowledge with specialists, who often come from philosophy, theology, or medicine. Among the mass of philosophers, I opt for three names and bodies of work that represent different viewpoints.

My first choice is Immanuel Kant as a representative of dutybased ethics grounded in reason. In Grundlegung zur Metaphysik der Sitten (Groundwork of the Metaphysics of Morals), Kant formulates two imperatives: first, the categorical imperative; that is, the absolutely necessary, in which an act is a good end in itself - and, second, the hypothetical imperative; that is, the possible, in which an act is a means of achieving the good (Kant 1785 (German): 51; 1998 (English): 25f). The categorical imperative says: "handle nach der Maxime, die sich selbst zugleich zum allgemeinen Gesetze machen kann"; "act only in accordance with that maxim through which you can at the same time will that it become a universal law" (Kant 1785 (German): 81; 1998 (English): 31).

The second choice is Peter Singer as a representative of consequence-based ethics. Singer's starting point is utilitarianism. He argues that acts are to be judged as good when they satisfy the greatest possible number, and that no interests may be given precedence before any others. And in line with this, he argues - in One World Now (2016) - that in a globalised world, where questions concerning climate, economics, legislation, and politics cross national borders, there is also a need for a global ethics.

My third choice is Martha Nussbaum as a representative of virtue ethics, and her paper "Non-Relative Virtues - An Aristotelian Approach". Nussbaum draws her inspiration from ancient literature, and her point of departure is human existence. Human beings strive after the good life, using their own feelings and internal ideas to achieve this goal. Nussbaum defines the good on the basis of some common human experiences (mortality, body, pleasure and pain, cognition, reason, the child's development, attachment, and humour) in order to go beyond the local and relative (Nussbaum $1988 ; 1993)$. Nussbaum's virtues, formulated with the assistance of Aristotle, recall various attempts to define transcendentals such as the true, the beautiful, and the good.

In response to the ethical demand, it could be argued that there is no firm foundation to stand on; there is no fixed, common starting point, no Archimedes Point or Arche. Where is the starting point for the right or the good in a world of religious, political, philosophical, and cultural plurality? Previously, God was perhaps an 
indisputable Archimedes point. But then I can ask: Which God or which gods - and in which interpretation? For Kant's reason, Singer's interests and Nussbaum's feelings and experiences also open up to plurality and need to be interpreted in practice. Which reason, which interests, which feelings, which experiences - and how? The right and the good are and remain relative and therefore problematic, as the right and the good often come with a universal ambition. Without a fixed starting point, the ethical demand risks being transformed into an individual responsibility (cf. Bauman 1993). Then the ethical is easily reduced to a non-binding slogan. Of course we ought to be ethical; but why, and how?

Inspired by Kant's imperatives, I would, however, like to try to formulate two moral rules. The first is categorical: treat the past as you want yourself and others to treat the present. Or, more specifically: protect, preserve, and use the past, as you want to protect, preserve, and use the present. The rule is relevant, as the traces of the past are very much part of the present. The second is hypothetical: act so that the past is a means of achieving the true, the beautiful, and the good. But the "you" and "others" do not need to represent a global consensus. Different individuals and groups social, political, cultural, religious, ethnic - may have different ideas about the true, the beautiful, and the good. So morality remains contextual and therefore relative.

The ethical demand encounters the past with history, memory, and heritage in several ways. First and foremost, ethics appears as rhetoric - the past ought to be preserved! Here ethics acts as a slogan that would implicitly make further argumentation superfluous. It appeals to common values and to a sense of collective responsibility. Heritage is elevated to an ethical sphere, being presented as priceless.

Ethics also appears as a canonical professional ethic. In view of the unethical ways in which the past was treated before our time, professional organisations have formulated rules for what is right and proper. It is stressed that there is a professional responsibility for acting in the right way. This is seen particularly clearly in the archaeological management of heritage, and it is found at both national and international level. Still, the ethical discussion can also be more (self-)critical and reflective (e.g. Vitelli 1996; Karlsson 2004; Sandis 2014; Ireland \& Schofield 2015).

One example of a canonical ethics is the International Council on Monuments and Sites (ICOMOS) whose statutes, the Charter for the Protection and Management of the Archaeological Heritage, 
describe the archaeological heritage as a moral duty for every human being (1990: Article 3, "The protection of the archaeological heritage should be considered as a moral obligation upon all human beings"; www.icomos.org). Here ethics becomes a professional duty formalised in statute paragraphs. But it is noteworthy that a "salvage campaign" such as that at Abu Simbel must be regarded as mistaken according to ICOMOS, since preservation ought to take place in situ: "Any transfer of elements of the heritage to new locations represents a violation of the principle of preserving the heritage in its original context" (1990: Article 6; www.icomos.org).

There is an extensive ethical debate, a debate about the right and the good, regarding the question of whether the past has been $(a b)$ used, generally by "others" before us or far away in the country where "things were done differently". A constantly topical question here is who has the (property) right to the heritage concerned (cf. Gillman 2010). Should heritage in the form of archaeological finds, books, art, or monuments be returned to the places from which they once came? Should the Parthenon frieze (or the Elgin Marbles) be transferred from the British Museum in London to the new Acropolis Museum in Athens (Greenfield 1996: 42ff; Bring 2015: 69ff)? But the ethical debate becomes most intensive when it approaches human beings and the human body. Nothing can generate debate like the handling of the dead - graves, crania, skeletons, mummies, and bog bodies (cf. Nilsson Stutz 2008).

Graves have been and are of central importance as expressions of collective identity. A source as early as Herodotus recounts a conversation in around 513-512 BCE in which Idanthyrus, King of the Scythians, is supposed to have said that he wanted to fight against the Persians for "our forefathers' graves". "But if nothing will serve you but fighting straightway, we have the graves of our fathers; come, find these and essay to destroy them; then shall you know whether we will fight you for those graves or no" (Herodotus, IV: 127, pp. 328f; cf. Kristiansen 2001: 148; 2004).

An ethical argument about graves appears in Sweden in the middle of the sixteenth century. The exiled Archbishop Olaus Magnus asserted that old monuments should be preserved as they had been erected with the intention of conferring immortality, just as he condemned the disturbing of graves as outrageous and a sin. The view that the graves of the dead should not be disturbed also turns up in directives and deliberations from the 1630s and up until the nineteenth century in Sweden (Olaus Magnus 1555 (Latin): I cap. xxx, pp. 49f; xvi cap. xlv-xlvi, pp. 564ff; 1982 (Swedish): 1, 
Chapter 30, p. 66ff; 16, Chapters 45-46, p. 759ff; cf. Jensen 2010: 153f). In several other religions, such as Judaism and Islam, the view is still that graves should be left in peace.

A discussion across the centuries setting out justifications, motives, and values gradually leads up to the present situation, in which most countries have legislation that protects traces of the past to varying degrees. And as a consequence of legislation and the expansion of heritage, there is now also "heritage crime" as a separate concept and a growing academic field (e.g. Grove \& Thomas 2014).

The ethical perspective has been given a prominent role since the Second World War. In that context, special attention has been paid to the difficult handling of the Holocaust with AuschwitzBirkenau as the iconic example, where genocide culminated in an industrial complex. Auschwitz-Birkenau became a World Heritage site at a relatively early stage (WHL 31, 1979). But many other places and situations characterised by evil and human beings as victims raise ethical issues. How can and should victims and executioners be remembered in texts, images, memorials, and museums? Understand or explain, tell or stay silent, remember or forget, preserve or destroy - everything is tested here, including relativism (e.g. Wyschogrod 1998; Macdonald 2009). It is also more generally observed that people in the present have a responsibility for the dead (cf. Southgate 2005: 53ff).

In Temps et récit (Time and Narrative), the philosopher Paul Ricoeur linked ethics with the narrative about the past. Here we encounter the view that every story about the past is a moral statement. The historian gives the victims of the past a voice. The victims deserve not to be forgotten, not to be trivialised or hidden by the history-writing of the victors (Ricoeur 1983-1985 (French); 1984-1988 (English)).

Ought the temples of Abu Simbel to have been salvaged from drowning, as actually happened - was it an ethical duty? In 1960, when the Director-General of UNESCO, Vittorino Veronese, was going to justify the Nubian campaign as a reaction to the flooding that would be caused by the Aswan High Dam, he did not use the concepts of ethics or morality. But Veronese did describe a difficult choice, a choice that would be "between a heritage of the past and the present well-being of a people", "between temples and crops". This was exactly why Egypt and Sudan sought international support (Veronese 1960: 7).

The same problem turned up again when the campaign was over and had to be justified once more. Then the Egyptologist Torgny 
Säve-Söderbergh wrote that those involved might ask "whether it was morally acceptable to collect millions of dollars for such a purpose in a world where millions of its inhabitants starve and innumerable children die of hunger or have no expectation of even a marginally decent standard of life" (Säve-Söderbergh 1987: 217f). Now, afterwards, we can conclude that the outcome was heritage, temples, crops, and electricity, but hardly welfare; that the temples were saved, but that many people continued to have relatively low living standards.

But neither Kant's, Singer's, nor Nussbaum's ethical deliberations provide any immediate guidance as to whether the temples of Abu Simbel ought to have been saved. Can their salvage be elevated to a general rule? Does their salvage satisfy as many interests as possible? Can their salvage contribute to a good life? In all three instances, the field is open to interpretation. "Salvage" of heritage can mean many things - on-site preservation, a relocation, documentation in text and photographs, and these days also digital documentation. Were the temples salvaged at all, considering the consequences of the move for their authenticity? Which group interests should be weighed against one another, and how? Who counts in this context? People living around Abu Simbel, in the Nile valley, or in Egypt; tourists, including all potential tourists; everyone in the world, including people who will live in the future? And what is the good life, and who should be allowed to have an influence on it? Without an absolute starting point, an Archimedes Point, Arche or God, ethics is just a finer but volatile word for doxa; that is, for attitudes and positions.

By way of thanks for their assistance in the Nubian campaign, several countries received temples - Debod came to Parque del Oeste in Madrid in Spain, Taffa to Rijksmuseum van Oudheden in Leiden in the Netherlands, Dendur to the Metropolitan Museum of Art in New York in the US, and Ellesiya to Museo Egizio in Turin in Italy. Ought these temples to be returned to Egypt in a postcolonial spirit, even though their move was completely legal and Egypt was not and is not a colony? With Kant, return would be a general rule. If any heritage is to be moved back, then all heritage ought to be moved back. With Singer, interests would be weighed against one another: Where can the greatest number of persons benefit from the presence of the monuments, in Nubia or in the urban centres of the West? Well, the greater number of people undoubtedly visit Madrid, Leiden, New York, and Turin (cf. Melotti 2011: 81ff). But is the context in the West meaningful, or have the temples become 
"places of forgetting"? Debod's temple, for instance, stands with no justification whatsoever in a park laid out in the 1890s; it used to be a rubbish dump, and it was the site of a massacre in the civil war in 1936. Or where do the monuments contribute most to the good life? The answers are not obvious.

With the ethical perspective, knowledge is probably a precondition, but narrative is subordinate. Truth and beauty have to serve goodness. To act in the right way, knowledge is needed; but the way in which it is conveyed may not be so very important.

The ethical demand is necessary, but it is problematic at the same time, both in theory and in practice. Discussion is made more difficult by a rhetoric in which ethics itself has become a watchword which is meant to make argument superfluous.

Of the three - truth, beauty, and goodness - the last is the most difficult to pin down. Even so, considering my deliberate choice of three virtues, my sympathies are with Nussbaum. The ethical demand must be determined from example to example, from situation to situation; virtues are relative. The canonical culture of heritage needs statutes, guidelines, values, and interests that can be measured and weighed. But moral rules for handling the history, memory, and heritage of the past cannot be discovered as something essentially existing. They need to be adopted through decisions made by communities, in groups, in nations, or globally; that is the only possible route to take.

\section{The ideas of the time}

We can ask Sisyphus why he is pushing a huge stone up a hill, why he is toiling uselessly. But supposing we get a reply, is it a credible one? Perhaps Sisyphus does not know why he is rolling the stone, or he has forgotten the reason. Sisyphus may reply stating what he thinks the reason ought to be, or what he believes that we would like to hear. Sisyphus may assert one reason, but act according to another. Or he can lie, and lead us on to a false trail. So we cannot be sure of our ability to uncover an actor's motives by listening to his own account of them. But irrespective of whether the stated motives are true or mendacious, they can reveal the ideas about the past and heritage that are current at a certain point in time.

The fact that we choose to interrogate Sisyphus at all is indicative of our own doubts about the meaningfulness of rolling a stone that keeps falling down again. We already have a preconceived 
opinion that Sisyphus's labour is futile. A "Sisyphean task" is in fact an expression used about an effort that is strenuous, but without any hope or result.

Wondering and asking why the past is recounted, remembered, and preserved, why history, memory, and heritage are having an upturn, may be a sign of crisis. For that which is obviously legitimate does not need any justifications. So when the past in conjunction with the humanities field - that is, the second culture for C. P. Snow - constantly needs to justify itself and face expectations to be useful, this may be a sign that the field is marginalised and on the defensive. The past must be defended both against concrete threats of destruction and against other priorities in society.

But questions about usefulness are nothing new. For example, the naturalist Carl Linnaeus (later ennobled as von Linné) defended his studies against the many who believed that his science was only about curiosity and a pastime for the idle: Hwartill duger det? [What use is it?] (Cui bono?) (Linnaeus 1752 (Latin); 1753 (Swedish)). Linnaeus argued that God had not created anything in vain, that nothing was without a use. With numerous examples, ranging from flies to grass, he demonstrated how something could be of use as, for instance, food, medicine, or building materials, either directly or indirectly. The question, which tormented Linnaeus, contains a fundamental doubt and a demand for justification current in the period, a demand rooted in the assumption that everything must be serviceable, be of use.

There are many kinds of usefulness, and as Linnaeus demonstrated, nothing is without a use. But when usefulness is demanded of the past and of the humanities, this amounts to an insistence that the field be justified within the premises of the predominant discourse of the period. Consequently, when the concepts "usefulness" and "benefit to society" are employed in the present-day debate, they mostly function as a political mantra that provides cover for a demand for profitability from something that present-day society just does not want to give priority; it is known that the question of benefit or profit will put the field on the defensive. The fact is that the defence of the past has to be formulated at a time, at a place, and in a society in which a distinction is made between what generates and what consumes resources, in which usefulness is contrasted with amusement, and in which use is often associated with economics, social science, medicine, natural science, and engineering, while amusement is associated with the humanities and literature. 
What is the past good for? One recurring theme is the topicality and relevance of the past, and therefore also its usefulness, in relation to the agenda of the present, but also in relation to future needs; something can be of use now or in the longer term. Justifications, motives, and values have constantly been updated or modernised so as to be geared to the great or burning issues of the time. To obtain legitimacy, there has been a conscious or unconscious appeal to what is well known, accepted, and relevant to the present, qualities that necessarily vary over time.

The classifications of motives and practices bear the stamp of the agenda of the present. Friedrich Nietzsche's three categories stemmed from the political tendencies of his own time - the monumental, which actively orientates itself backwards to a golden age; the antiquarian, which passively preserves; and the critical, which actively seeks the golden age in the future. In simplified terms, the categories represent a reactionary, a conservative, and a revolutionary perspective - or three social and political groups that belong to Nietzsche's time: the aristocracy, the bourgeoisie, and the workers. By contrast, Svante Beckman's division into four categories comprising norms and necessity, usefulness and entertainment, forms a mirror image of sectors in the modern welfare state, in which time is divided up between external demands and personal needs, as well as between work and leisure. And my own triple categorisation into truth, beauty, and goodness can be seen as a positioning in the present debate, bridging the two cultures of heritage - a positioning legitimised by a reuse of philosophical concepts that can point out a direction, but whose content is constantly renewed. Consequently, we are unavoidably entangled in our own time.

To obtain funds for a salvage action at Abu Simbel, it was necessary for Vittorino Veronese and UNESCO to employ rhetorically persuasive expressions which were able to engender widespread comprehension in their own period. Herodotus, Ibn Khaldûn, Leopold Ranke, Alois Riegl, Marc Bloch, Torgny Säve-Söderbergh, David Thomson, Eric Hobsbawm, Michael Shanks, Christopher Tilley, and Cornelius Holtorf - all have argued in line with or against their own period. And Carl-Axel Moberg's overview, in terms of the history of ideas, of justifications for archaeological research is very much a catalogue of varying current "uses" - from evidence of the relevant country's greatness to a mere pastime (cf. Moberg 1984).

Views of what usefulness amounts to have varied over time; but these days it is usually defined in terms of economic growth as both the means and the end, surrounded by a number of secondary 
themes that may be either prerequisites for or consequences of growth. The past in its wide-ranging sense, encompassing history, memory, and heritage, is thus regarded as a resource for experiences, recreation, and travel $-\mathrm{a}$ resource that is of growing economic importance. The designation of Abu Simbel and other sites as World Heritage sites is expected to promote the influx of tourists, thereby contributing to income and jobs, even though the development of cultural tourism is not without its problems (cf. Bourdeau et al. 2015).

But history, memory, and heritage are a resource comprising knowledge, narratives, and experience of broader relevance. It is thus relatively easy to find current examples in which archaeologists and others wish to activate knowledge about the past in order to contribute to solving the great issues of our time; that is, issues involving sustainable development, climate change, population growth, poverty, migration, diversity, human rights, political trust, community, and peace (e.g. Silverman \& Fairchild Ruggles 2007; Sabloff 2008; Little 2009; Westman \& Tunón 2010; Fredengren 2012; Högberg 2013; Aronsson 2015; Räkna med kulturarvet ["Count on heritage"], 2017; Schiffer 2017). The narratives, finds, and sites of the past already play a central role in a cultural tourism that is able to entertain as well as enlighten. However, heritage can be used in many other contexts as well, including issues involving identity, good health, and ethics. In short, heritage can contribute to a better world (cf. Aronsson 2009).

At the same time, it must be said that if the humanities - the study of the past, history, memory, and heritage - were to focus wholly on usefulness for the present or on the great issues, if there were no place for free basic research, curiosity, and unrestricted exploration, this would amount to losing the unexpected, which has turned out to be of crucial importance from a historical point of view. Even the study of the past needs its serendipity, the fortuitous discovery of something in the past other than the very thing that was being looked for - something unexpected and "strange".

The past has had meaning and value for thousands of years and has therefore already proved its sustainability or usefulness in varying conditions, but each period has understood or explained this in its own way. The justifications, motives, and values have varied, just as the arguments for scholarly and scientific pursuits have varied over time (cf. Sundin 1996). The crucial point is whether we are in Cairo in 1813, in Basel in 1874, in Paris in 1960, or in Lund in 2020, and what matters is whether it is the sheik, the 
philosopher, the director-general, or the archaeologist who is supplying the justifications and making the assessments. The question of who is to be persuaded is equally crucial: is it the president, the engineer, the tourist manager, the sceptical taxpayer - or the writer personally?

What is seen as meaningful depends on the context - on who is writing or speaking and who is expected to read or listen. The words have varied along with what someone could, ought to, or wanted to express in that period, at that place, or in that situation. Hence meaning is created within or in relation to a discourse. We say what we can, ought to, or want to when speaking to power, our colleagues, the public, and perhaps our own conscience.

What is the meaning of the past, of history, memory, and heritage? We must now conclude that the method of uncovering meaning through the actors' own justifications, through motives and values, leads to new questions, since the multifarious replies are bound up with the leading ideas and practices of the period. Does that mean that the ideas of the period are a mental prison that determines what can be said, or do the ideas of the period create new opportunities? Is the episteme restricting or liberating?

In Les mots et les choses (The Order of Things) (1966 (French); 1971 (English)) and L'archéologie du savoir (The Archaeology of Knowledge) (1969 (French); 1972 (English)), Michel Foucault used the concept of the episteme, from the Greek word meaning knowledge, about how and therefore also what it was possible to think, write, and say during a particular historical period. This would mean that the classical and the modern epochs are each characterised by their own episteme or their own discursive formation. It is, however, something of a contradiction that - also according to Foucault there can be several epistemes at the same time. Here the episteme approaches other concepts such as mentality, paradigm, and discourse. Foucault himself thus used the concept of discourse in a way that is difficult or impossible to differentiate from the episteme.

It is tempting to reuse the concepts of episteme and discourse when trying to establish how the past acquires meaning. As a concept, the episteme can be useful in understanding how history, memory, and heritage are subordinated - at an initial, fundamental level - to a requirement of usefulness: everything must self-evidently be of use in relation to its own period. Thereafter, discourse as a concept may be employed at the next level in order to understand how expressions concerning the usefulness of the past vary with and within the demands of the period. 
Here conflicts may arise between different discourses, between canonical and critical heritage, between representatives of different research traditions, and in the prioritisation of either the true, the beautiful, or the good. These conflicts are manifested in a polarised debate about the right heritage policy, a debate in which each distinct tradition attempts to define the field in its own way. In relation to that debate, political parties try to define heritage so that it fits their specific agenda - heritage as something enduring or something changeable, something delimited, national, or universal.

The episteme's requirement of use is seen in both cultures of heritage. For both the canonical and the critical culture can agree that the past ought to be of use, but they coalesce around different discourses and therefore have completely different ideas concerning what is of use. Not unexpectedly, the canonical culture is most visible in the defence of the usefulness of the past, supplying justifications, motives, and values, whereas the critical culture dominates the debate about $(a b)$ use. The starting point of my own inquiry is also subordinated to the episteme. Because asking about the importance of the past entails looking for what is of use, even if the pursuit also includes curiosity allied to a sense of wonder.

Still, the concepts of episteme and discourse can easily become a philosophical straitjacket. There is an absence of a dynamics that allows for individuality, variation, and change, permitting movements across the constructed time limits of the episteme and the enforced roles of the discourse. Human beings are denied the ability to use their imagination to think beyond their own present and situation - think in the past and the future, in other periods, at other places, and from other perspectives. The episteme and the discourse do not allow human beings any freedom - and therefore no responsibility for their actions either, neither as individuals nor as collectives.

Justifications, motives, and values may be something different from, and more than, a mechanical and enforced reflection of the ideas and roles of a period. This is, first, because human beings do not discover the meaning of the past, but create its meaning in dialogue with their present. With new justifications, motives, and values, the past is given a meaning that it did not previously possess. Meaning is therefore in constant change, constantly fluid. And, second, because new justifications, motives, and values open the way to fresh perspectives on the past which are different from those already known. So the past is a resource that can constantly be reused in new and unexpected ways. As the time, place, and 
situation change, new possibilities arise of making creative use of the past - as a source of knowledge, and as a starting point for narratives or ethical deliberations. The recurring theme, the relevance of the past, is an expression not of weakness but of strength: the past possesses the very ability to be relevant and sustaining as a resource in varying circumstances.

It is meaningful to ask Sisyphus why he is pushing a great stone up a hill, even though the stone rolls down to the plain again, because justifications, motives, and values create meaning and help to shape the actions of the future. Let us now take a closer look at how Sisyphus affects the stone and the stone affects Sisyphus. What meaning does, can, or should the past have, if practices are examined? What is it that actually happens to the past? 


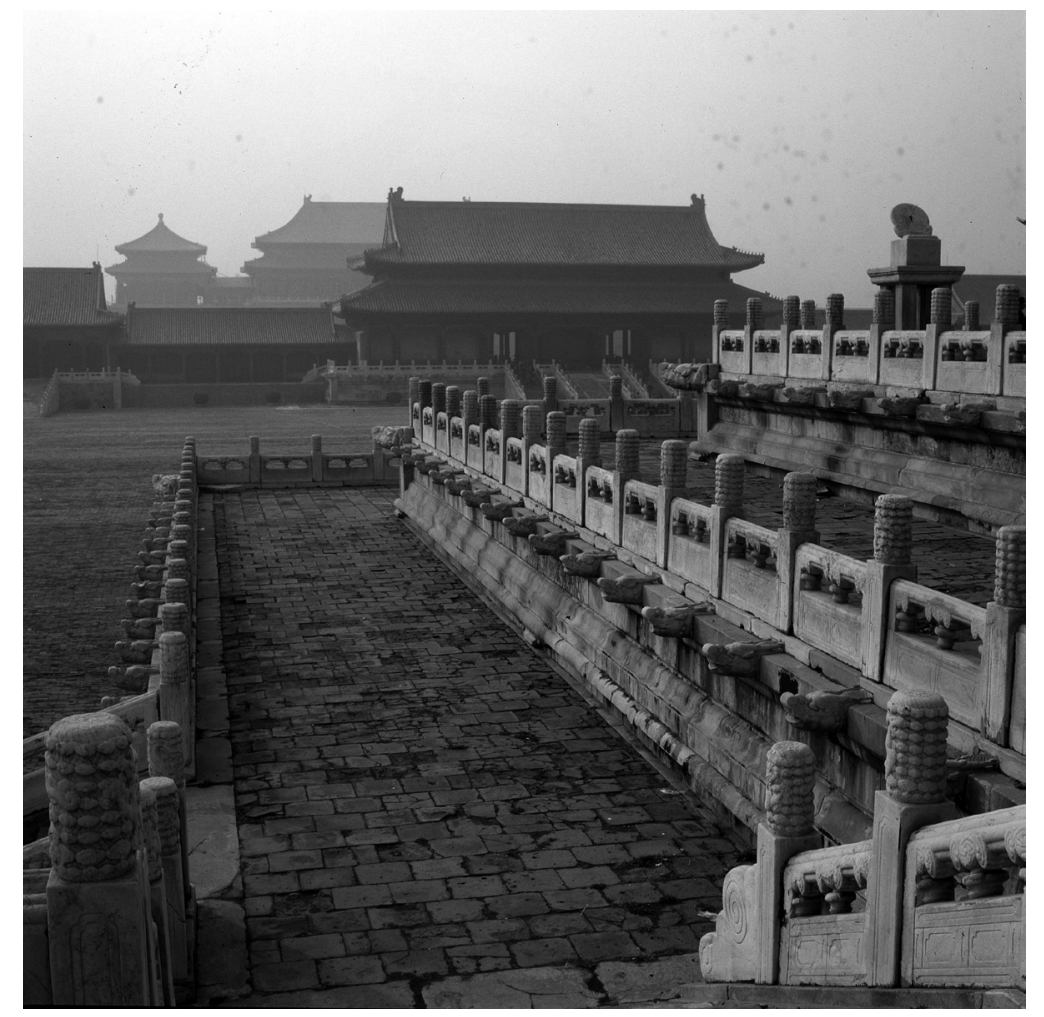

Figure 3 The Forbidden City in Beijing. Photo @ Jes Wienberg, 1982. 